and Government departments concerned to arrange a new lease to the College for 999 years from midsummer 1956 at a rental commencing at $£ 5,000$ and rising over ten years to $£ 25,000$ a year.

The Commission's office at 1 Lowther Gardens provides accommodation also for the London headquarters of the British School at Rome, to which the Commission now contributes $£ 8,000$ a year, and for the Institute of Physics and the Physical Society. Of the expenditure of $£ 324,759$ during the ten years January 1, 1951-December 31,1960 , 244,822 was on direct educational grants. A now Record of the Science Research Scholars of the Royal Commission for the Exhibition of 1851, 1891-1960, has now been compiled, and it may be noted that of the 905 Scholars, 99, including 34 from overseas, became Fellows of the Royal Society, of which two were elected president, eight won Nobel Prizes (Pp. iv +107 . London: Royal Commission for the Exhibition of 1851, 1961. 12s. 6d.). The Record lists separately Science Research Scholars appointed during 1891-1921, Overseas Scholars appointed since 1922 and Senior Students appointed since 1922. There are indexes to Scholars and to the Institutions from which they came.

\section{Experimental Eye Research}

THE scientific literature on the eye and vision is dispersed in journals representing many different disciplines, and visual scientists have for long deplored the fact that they had no journal of their own. Now they are to have at least two. For the appearance last June of Vision Research (Pergamon Press) (see Nature, 191,$650 ; 1961$ ) is followed by the present debut of Experimental Eye Research (Academic Press). Congratulations are due to Academic Press for the fine quality of Experimental Eye Research, the first number of which appeared in September (1, No. 1; September 1961. Pp. 97. Published quarterly. Vol. 1, approx. 400 pages. (London: Academic Press, Inc. (London), Ltd.; Now York: Academic Press, Inc., 1961). 115s.; 16 dollars). The object of this quarterly journal is the publication (in English) of original papers on the anatomy, physiology, biochemistry and biophysics of the eye. "Contributions on such subjects as the production and circulation of ocular fluids, the fine structure, biochemistry, biophysics and metabolism of the eye tissues, the photochemical processes rolated to visual function, and the neuromuscular mechanisms in the control of eye movements will be preferred." The editors-in-chief are Dr. E. A. Balazs, of Harvard Medical School, and Dr. Hugh Davson, of University College, London. They are supported by a group of leading workers forming an editorial board of five and an advisory board of nine. A study of the first issue reveals a high standard of editorial policy and also confirms the initial impression that the main interests of the publication are the minute anatomy and vegetative physiology of the eye. Since the interests of the 'rival' publication, Vision Research, are centred more on the physiology of vision, there is less overlap in the scopes of the two journals than might appear.

\section{Engineering and Television}

Two publications of the British Broadcasting Corporation issued to mark the twenty-fifth anniversary of B.B.C. Television direct particular attention to the work done by its engineering division during the period under review. The first, Twenty-five Years of B.B.C. Television, is one of its periodic Monographs, and has been prepared by one of the original members of the B.B.C., Sir Harold Bishop, now director of engineering (No. 39. Pp. 41 (14 plates). London: British Broadcasting Corporation, 1961. 5s.). After a survey of the events and developments which led to the start of the B.B.C.'s high-definition television service, the monograph describes the main engineering developments during the past quarter of a century. Particular attention is directed to those techniques which have been originated by the B.B.C., or which are utilized in a specially noteworthy manner in the services of the B.B.C. There is also a brief review of the B.B.C.'s contributions to probable future developments, including colour television and a change of standards. The second publication, B.B.C. Television: a British Engineering Achievement, is written in a more popular style, and gives a narrative account of how television works, the early growth of the services and what engineering services and techniques are involved to bring television into the home. The brochure is well written, with good illustrations and, like so many B.B.C. publications, is remarkably cheap (Second edition, revised. Published on the 25th Anniversary of B.B.C. Television. Pp. 64 London: British Broadcasting Corporation, 1961. $3 s$. 6d.). It should find its way to bookstalls as well as libraries in schools and other places.

\section{Astronomical and Nautical Almanacs}

Two ephemerides have recently been published for the year 1962, one by the U.S. Government and the other by the Indian Government. The American Ephemeris and Nautical Almanac is unchanged with regard to the presentation of material (Pp. vii +514 . Washington, D.C.: Government Printing Office, 1960. 4 dollars). The Indian Ephemeris and Nautical Almanac (Pp. xxviii + 460. Delhi: Manager of Publications, 1961. Rs. $14.00 ; 22 s$.) is closely similar to the American Ephemeris, though more restricted in scope, but in addition contains a section on the Indian Calendar. The 1962 edition contains four new sections: (1) ephemeris for physical observations of the Sun; (2) ephemeris for physical observations of the Moon; (3) centre of mass of the solar system; and (4) local circumstances of occultations of bright stars and planets visible in India.

\section{Technical Publications of the Oak Ridge National Laboratory}

THe publication $O R N L$ 61-6-27 contains a list of papers published in journals and presented at meet. ings, reports issued, and theses completed, during 1960 , by the members of the staff of the Oak Ridge National Laboratory, Oak Ridge, Tennessee (Pp. $v+107$. Oak Ridge, Tennessee: Oak Ridge National Laboratory, 1961). Reprints of many of the articles can be obtained on request either from the Laboratory, or of papers presented at scientific meetings from the authors concerned. There is an author index, and the various articles are grouped within the sections according to subject, biology, chemistry, physics, etc. The prices of the ORNL reports are given, and the reports, except those indicated as 'not for sale', can be obtained through the Office of Technical Services, Department of Commerce, Washington 25, D.C.

\section{National Conference of Standards Laboratories}

To help meet the needs of science and industry for improved uniformity and greater precision in calibration and measurements in all areas of the physical 